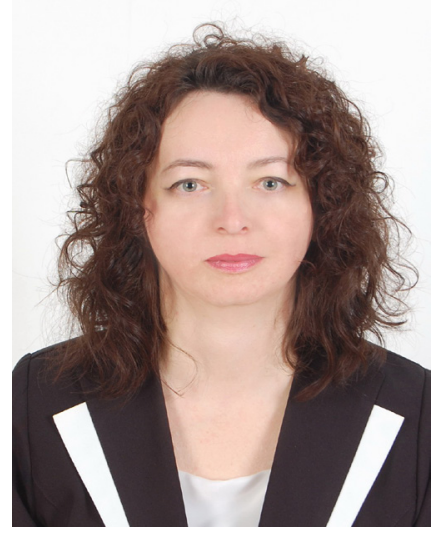

Лариса Наконечна, кандидат філологічних наук, доцент кафедри педагогіки початкової освіти, ДВНЗ «Прикарпатський національний університет імені Василя Стефаника» (м. Івано-Франківськ, Україна)

\section{Larysa Nakonechna,}

PhD in Philology, Associate Professor,

Department of Pedagogy of Primary Education, Vasyl Stefanyc Precarpathian National University (Ivano-Frankivsk, Ukraine) larysa.nakonechna@pu.if.ua ORCID ID 0000-0003-0743-4576

УДК 378.147:372.881

\title{
ОСНОВИ ФОРМУВАННЯ ЛЕКСИЧНОЇ КОМПЕТЕНЦІЇ МАЙБУТНІХ УЧИТЕЛІВ ПОЧАТКОВОӤ ШКОЛИ ЗАДЛЯ ПРОФЕСІЙНОЇ ДІЯЛЬНОСТІ В УМОВАХ ДІАЛЕКТНОГО СЕРЕДОВИЩА
}

Анотація. Статтю присвячено питанню формування лексичної компетенції майбутніх учителів початкової школи, зокрема задля їхньої успішної професійної діяльності в умовах діалектного середовища.

Розглянуто низку визначень поняття «лексична компетенція» як вагомої складової комунікативної компетентності, проаналізовано погляди сучасних лінгводидактів на проблему формування лексичної компетенції молодших школярів і студентів спеціальності «Початкова освіта».

Опрацювання наукових лінгводидактичних праць дало змогу авторові виокремити низку складових поняття «лексична компетенція» загалом і «лексична компетенція учителя початкової школи» зокрема; визначено пріоритетні напрямки роботи у системі підготовки студентів спеціальності «Початкова освіта» до педагогічної діяльності в умовах діалектного середовища.

Обґрунтовано необхідність уведення у систему підготовки студентів педагогічних ВНЗ тем і дисциплін, спрямованих на формування готовності майбутніх учителів мови до роботи в умовах місцевих говірок.

Зважаючи на вагомість порушеної проблеми для удосконалення системи підготовки майбутніх учителів початкової школи, як і методики формування мовної особистості молодших школярів, і водночас на недостатнє її опрацювання у педагогічних наукових і методичних джерелах, маємо на меті розглянути особливості формування лексичної компетенції студентів спеціальності «Початкова освіта» у системі їхньої підготовки до професійної діяльності в умовах місцевих говірок.

Методологічними засадами дослідження $€$ науково-концептуальні положення про взаємозв'язок мови і мовлення, ї визначальне місце і роль у мовному розвитку особистості, концепції побудови освіти на засадах формування національно свідомої мовної особистості.

Отже, формуванню лексичної компетенції належить провідне місце у системі мовної підготовки майбутніх учителів початкової школи.

Ключові слова: комунікативна компетентність, лексична компетенція, діалект, студент спеціальності «Початкова освіта», початкова школа.

\section{BASES FOR THE FORMATION OF THE LEXICIAL COMPETENCE OF FUTURE PRIMARY SCHOOL TEACHERS FOR FUTURE PROFESSIONAL ACTIVITY IN THE DIALECT ENVIRONMENT}

\footnotetext{
Abstract. The article deals with the formation of the lexical competence of future elementary school teachers in the program, which prepares for the work activity in the conditions of the dialectal environment.

The author analyzed several definitions of the «lexical competence» concept, the scientific's' views for the formation of lexical competence of primary pupils and students which study «Primary Education» specialty.

Also, the author worked out a number of pedagogical and methodological works, defined the concept of «lexical competence» and "lexical competence of the primary school teacher», defined the directions of preparation for work in the dialectal environment those students who study «Primary education» specialty the author argued the need of the universities disciplines which form the readiness of future language teachers for the work in the dialectical environment.
} 
The purpose of the article is to analyze the formation of lexical competence of the «Primary education» specialty students while preparation for the work in the dialectal environment. The purpose is due to the lack of the Programs, which guide how teachers should work with dialect speaking pupils.

The author analyzed the current Programs of the Ministry of Education and Science of Ukraine for the primary schools, and found that there are no any recommendations to the teacher on how to work in local dialects there. Similarly, there are no exercises for studying the literary language through the comparison with dialecticisms in Ukrainian language textbooks. On the other hand, we should not ignore the active functioning of the dialects and the fact that primary school teachers work with pupils who are dialect speakers.

The article author described the results of the researching, which proves the effectiveness of studying the literary Ukrainian language through comparison with the local dialects that children speak.

The urgency of the topic is connected with the fact that it is necessary to improve the system of training of future elementary school students and the methodology of formation of primary pupils' language personalities.

So, formation of lexical competence has the leading place in the language training for primary school pupils.

Keywords: communicative competence, lexical competense, dialect, student of speciality «Initialstudies».

\section{ВСТУП}

Постановка проблеми. Реформування системи сучасної вітчизняної початкової освіти зосереджує увагу педагогів ВНЗ на удосконаленні підготовки студентів-майбутніх учителів початкових класів до формування мовно-мовленнєвих компетенцій молодших школярів.

Сучасний учитель постав перед завданням не так дати учням певні знання з мови, як сформувати особистість, котра володіє усіма засобами мови і мовлення, що забезпечує їй повноцінну комунікацію у різноманітних мовленнєвих ситуаціях. Відповідно, сучасні вимоги до мовно-мовленнєвої підготовки учнів початкової школи спонукають до коригування змісту і методів системи підготовки студентів спеціальності «Початкова освіта». Адже вчитель не лише має мати необхідні знання з мови, але й уміти досконало послуговуватися ними у власному мовленні за будь-яких обставин, сам має бути добрим комунікатором, оскільки мовлення і комунікативна поведінка вчителя є, безумовно, прикладом для учнів, засобом формування їхнього мовлення.

Аналіз останніх досліджень і публікацій. Одним із завдань, що стоїть перед учнями у процесі вивчення мови, є оволодіння лексичною компетенцією, яка поряд з іншими компетенціями формує комунікативну компетентність як «комплексне застосування мовних і немовних засобів 3 метою комунікації, уміння орієнтуватися в ситуації спілкування, ініціативність спілкування» (Богуш А.М., 1998, с.12).

У «Державному стандарті початкової освіти» (від 21 лютого 2018 р.) зазначено: «до ключових компетентностей належить... вільне володіння державною мовою, що передбачає уміння усно і письмово висловлювати свої думки, почуття, чітко та аргументовано пояснювати факти, відчуття краси слова, усвідомлення ролі мови для ефективного спілкування та культурного самовираження, готовність вживати українську мову як рідну в різних життєвих ситуаціях» (Державний стандарт початкової освіти, 2018, с 2), а здобувач початкової освіти «взаємодіє з іншими особами усно, сприймає і використовує інформацію для досягнення життєвих цілей у різних комунікативних ситуаціях» (Державний стандарт початкової освіти, 2018, с. 6), що, фактично, розкриває зміст поняття «комунікативна компетентність».

Володіння нормативним лексико-граматичним складом мови - першочерговий «видимий» показник не тільки культури мовлення, але й загального рівня освіченості й культури особистості, їі прагнення розвитку і самовдосконалення, її уміння вчитися; необхідний засіб ефективної соціалізації та реалізації. Саме від умінь і знань учителя, зокрема початкової школи, залежить успішність формування i, зрештою, сформованості основних життєво необхідних компетентностей, серед яких і комунікативна.

Питання професійної мовної підготовки майбутніх учителів початкової школи були і $є$ в центрі зацікавлення низки науковців, як-от: Л. Варзацька, В. Желанова, К. Климова, Л. Коваль, С. Мартиненко, М. Оліяр, В. Собко, М. Стахів Л. Романишина, Л. Хомич. Лексична компетенція рідної та іноземної мови школярів і студентів $€$ предметом досліджень таких науковців, як С. Амеліна, О. Аматьєва, А. Богуш, Н. Горбунова, С. Куліш, С. Ніколаєва, Н. Сіранчук, та ін. Однак, як засвідчує наше опрацювання відповідної наукової і методичної літератури, варто звернути увагу дослідникам на питання підготовки студентів педагогічних спеціальностей до професійної діяльності учителя в умовах місцевих говірок.

META I ЗАВДАННЯ ДОсЛІДЖЕНнЯ. Зважаючи на вагомість порушеної проблеми для удосконалення системи підготовки майбутніх учителів початкової школи, як і методики формування мовної особистості молодших школярів, і водночас на недостатнє її опрацювання у педагогічних наукових і методичних джерелах, маємо на меті розглянути особливості формування лексичної компетенції студентів спеціальності «Початкова освіта» у системі їхньої підготовки до професійної діяльності в умовах місцевих говірок.

МЕТОДИ ДОслІДЖЕНня: історико-педагогічної ретроспективи, теоретичного аналізу, синтезу та узагальнення, порівняльно-зіставний, анкетування, бесіди.

\section{РЕЗУЛЬТАТИ ДОСЛІДЖЕННЯ}

Обізнаність з лексичним складом мови є вагомою основою формування і реалізації низки компетенцій, що в комплексі становлять базову комунікативну компетентність.

Так, наприклад, Ю. Федоренко виокремлює такі основні складники комунікативної компетентності, як-от:

1) мовну (лексичні, граматичні, фонетичні, орфографічні знання); 
2) мовленнєву (охоплює вміння аудіювання, читання, письма та мовленнєві вміння);

3) лексичну (знання лексики і мовленнєві лексичні навички);

4) граматичну (знання граматики і мовленнєві граматичні навички);

5) фонетичну (фонетичні знання, мовленнєво-слухо-вимовні навички);

6) соціокультурну (стосується країнознавства та лінгвокраїнознавства);

7) компетенцію, що стосується процесу говоріння (Федоренко Ю., 2002, с. 63). Аналіз кожного 3 цих компонентів засвідчує очевидну неможливість ефективної реалізації жодного з них без знання (навіть обмеженого) лексики і вміння нею послуговуватися, оскільки ні граматична, ні фонетична, ні навіть соціокультурна компетенції не можуть бути повноцінно презентовані поза лексичною.

у наукових, методичних та нормативних джерелах натрапляємо на низку визначень поняття «лексична компетенція», які, взаємодоповнюючи один одного, підкреслюють певні її ознаки.

1. Так, у «Загальноєвропейських рекомендаціях з мовної освіти» лексичну компетенцію визначають коротко: це «знання і здатність використовувати мовний словниковий запас» (Загальноєвропейські рекомендації з мовної освіти: вивчення, викладання, оцінювання, 2003, с.7). Лігнвісти і лінгводидакти, котрі глибоко досліджують процеси комунікації рідною та іноземною мовами, а також навчальні компетентності і компетенції, подають розлогі, детальні визначення.

2. Так, за Н. Горбуновою (Горбунова Н. В., 2009), «лексична компетенція - це здатність миттєво викликати з тривалої пам'яті еталон слова залежно від конкретного мовленнєвого завдання та включати це слово в мовленнєвий ланцюг. Лексична правильність мовлення визначається сталістю лексичних мовленнєвих навичок таких, як розпізнавання і розуміння лексичних одиниць активного і пасивного мінімумів при аудіюванні і говорінні».

3. С. В. Смоліна (Смоліна С.В., 2010, с.16) визначає лексичну компетенцію як«здатність людини до коректного оформлення своїх висловлювань і розуміння мовлення інших, яка базується на складній і динамічній взаємодії відповідних навичок, знань та лексичної усвідомленості. ЛК включає в себе лексичні навички, знання і загальну мовну усвідомленість або здатність їх використання в усіх видах мовленнєвої діяльності (МД)». У визначенні В. Новосьолової натрапляємо на виокремлення компоненту «усвідомлення» і «мотивація» вивчення лексики: «лексична компетентність полягає в усвідомленому й умотивованому оволодінні лексичними засобами мови й умінні користуватися ними» (Новосьолова В., 2014, с. 19) .

Також науковець акцентує на тому, що «лексична компетентність передбачає не лише наявність багатого словникового запасу, а й уміння використовувати наявні в активі лексичні елементи в процесі мовлення для вираження своєї позиції й ставлення до сказаного, здатність варіювати лексичними засобами залежно від сфери й ситуації, у яких відбувається комунікативний процес» (Новосьолова В., 2014, с. 19).

Узагальнивши погляди сучасних учених на лексичну компетенцію, Г. П. Ватаманюк подає розгорнуте і конкретизоване визначення цього поняття. Вона визначає його як «наявність певного запасу лексичних одиниць (ЛО) з урахуванням віку школярів, здатність адекватно їх використовувати: коректно вимовляти і писати, правильно організовувати граматично, розуміти на слух і в процесі читання, оперувати ними в актах комунікації у потрібному темпі і в різноманітних значеннях, доречно вживати образні вислови, прислів'я, приказки, фразеологічні звороти для досягнення відповідного комунікативно-функціонального результату» (Ватаманюк Г., 2017, с. 184).

4. За Н. М. Сіранчук, «лексична компетентність - здатність особистості швидко і якісно, на рівні програми оперувати не словами, а семантичними полями, зі складу яких людина обирає потрібне слово, словосполучення, щоб із можливою точністю висловити свою думку в мовленні, спілкуванні, з опорою на граматичну структуру мови (макроструктуру мови)» (Сіранчук Н., 2018, с. 40).

При цьому науковець обгрунтовує різницю між термінами «лексична компетенція» і «знання, уміння та навички», зазначаючи, що «поняття лексична компетентність учня значно ширше за поняття знання, уміння та навички з лексики оскільки зосереджує в собі спрямованість особистості (мотивацію, ціннісні орієнтири та ін.), її здатність долати стереотипи, передбачати мовленнєві ситуації, гнучкість мислення; характер - самостійність, цілеспрямованість, вольові якості. Лексична компетентність учня початкових класів є однією з інтегрувальних якостей особистості школяра, яка уможливлює свідомо і творчо визначати і здійснювати власне життя, розвивати власну індивідуальність, досягати успішної, оптимальної життєдіяльності» (Сіранчук Н., 2018, с. 45).

Визначення Н.М. Сіранчук вважаємо найточнішим, оскільки, по-перше, дослідниця, вдало послуговуючись лінгвістичними термінами, вказує на більш досконалий рівень володіння лексикою - оперування компонентами семантичних полів мови, що вимагає від мовця уміння встановлювати і відчувати семантичні зв'язки між лексемами (наприклад, синонімічні, антонімічні, паронімічні і т. ін.) і вживати найдоречніший компонент відповідного семантичного поля, i, по-друге, з лінгвістичного погляду, висловлення формують не слова (лексеми), а словоформи, які є одиницями граматичної системи мови, а це вимагає від мовця також доброго знання граматики. Інакше кажучи, дослідниця, розглядаючи лексичну компетенцію, небезпідставно взяла до уваги такі характеристики лексичної структури мови, як наявність численних семантичних полів і неподільну єдність лексичної та граматичної систем мови.

Також вважаємо слушним твердження В. В. Виноградова, у якому акцентовано на психологічній мотивації належного володіння лексичною компетенцією, що «...виявляється в умінні зрозуміти партнера у спілкуванні, 
подивитися на себе його очима і взаємно скоригувати поведінку, допомогти йому виявити власний сильний бік, що вкрай важливо для спільної діяльності» (Сіранчук Н., 2018, с. 42). Такий погляд на лексичну компетенцію, як загалом і на комунікативну компетентність, може, вважаємо, увиразнити, доповнити мету свідомого опанування лексико-семантичним складом мови та вдосконалення мовленнєвих умінь і навичок.

Таким чином, узагальнивши погляди лінгводидактів на лексичну компетенцію як одну з основ комунікативної компетентності і проаналізувавши власні спостереження, виділяємо такі складники лексичної компетенції:

1) когнітивна готовність - наявність знань словникового складу мови відповідно до віку й інтелектуального розвитку (слова, фразеологізми, лексичні словосполучення різної тематики і галузей знань (науки, мистецтва, суспільного життя і т. ін.), емоційно-експресивна лексика, їхні семантичні відтінки та стилістичні особливості вживання);

2) практична готовність - сформованість лексичних навичок та умінь застосовувати здобуті знання у мовленні залежно від комунікативної ситуації, мовленнєвий досвід;

3) позитивне ставлення до рідної (іноземної) мови;

4) готовність до самостійного пізнання і вдосконалення.

3 огляду на те, що предметом нашої розвідки є лексична компетенція вчителя початкових класів, вважаємо за необхідне уточнити і доповнити подані вище складові цієї компетенції іншими компонентами, не менш важливими в педагогічній діяльності вчителя:

1) знання загальної педагогічної і конкретної предметної термінології;

2) знання лексичних одиниць, що використовуються у початковій школі (активного і пасивного словникового запасу учнів певного року навчання);

3) нормативність і багатство мовлення;

4) уміння адекватно вживати лексичні одиниці в педагогічному спілкуванні, зокрема в комунікативних ситуаціях «учитель-учень», «учитель-батьки»;

5) здатність до мовленнєвої творчості;

6) уміння, завдяки володінню мовним багатством, дохідливо пояснити учням навчальний матеріал;

7) уміння адаптувати незрозуміле учням мовлення (як, наприклад, пояснити літературні лексеми більш зрозумілими молодшим школярам діалектними словами чи словами мови меншин);

8) розуміння вагомості впливу слова на формування національно-мовної особистості школяра.

5. В Україні як державі з давніми мовними традиціями активно побутують місцеві говори і говірки, що становлять три наріччя (північне, південно-західне і південно-східне), більшою чи меншою мірою віддалені від сучасної нормативної літературної мови. Це природно зумовлює ситуацію паралельного функціонування діалектного і літературного мовлення, що зазвичай представлене, залежно від місцевості, діалектним мовленням з елементами літературного або ж літературного з елементами діалектного (інші різновиди національної мови до уваги зараз не беремо). Також цілком природна і водночас звична ситуація, коли учні початкової школи $€$ носіями виразного діалектного мовлення, яке їм більш близьке і зрозуміле, ніж літературне, і, звичайно ж, сприймається як цілком нормативне. Адже послуговуються ним з раннього дитинства і засвоїли від батьків і найближчого оточення. Відповідно, «будь-яке відхилення від того, що вже усталилось у діалектному мовленні [наприклад, літературне - Л.Н.], сприймається як щось ненормативне, незвичне» (Дудик П., 2005, с. 40).

Саме вчитель початкових класів завдяки художнім і навчальним текстам, а також власному нормативному мовленню одним з перших уводить своїх вихованців у світ літературної мови. Вважаємо вкрай важливим, щоб учитель, котрий працює в умовах діалектного середовища, позитивно ставився до місцевої говірки, усвідомлював роль діалектів у становленні літературної мови, насамперед, задля того, щоб в очах дитини не знецінити мовлення її і рідних, не сформувати зневажливого ставлення до найдавніших лексем і форм української народної мови. Адже, як зазначають відомі діалектологи та стилісти, «діалектне мовлення теж по-своєму нормативне,... носії діалекту реалізують усі можливі діалоги й монологи в рідній для них діалектній мовній формі, дотримуючись при цьому усталених у мовленні свого краю (району, села, селища) елементів мовлення» (Дудик П., 2005, с. 40).

В останні десятиліття в Україні спостерігаємо зростання зацікавленості діалектами як серед науковців, діячів культури і мистецтва, так і серед педагогів. Якщо в радянський час йшлося про викорінення діалектних елементів з мовлення учнів, то зараз - про те, щоб учнів-носіїв діалектного мовлення вчити розрізняти комунікативні ситуації, у яких варто послуговуватися говіркою (наприклад, спілкування з батьками, односельцями, котрі $€$ носіями говірки учня) або ж літературною мовою (наприклад, під час навчального процесу, у спілкуванні поза межами рідної говірки і. т. ін.). Зазначимо, що серед мовознавців поширюється термін «ділінгвізм», який означає «вільне володіння як нормами літературної мови, так і своєї говірки», і таке вміння поступово стає правилом ввічливості ґречної людини.

На думку лінгводидактів і вчителів-практиків, котрі досліджували вплив місцевого мовлення на процес вивчення літературної мови (К. Я. Климова, І. М. Хом'як, Л. М. Симоненкова та ін.), формування мовномовленнєвої і зокрема лексичної компетенції учнів в умовах виразного діалектного оточення передбачає обов'язкове врахування говіркових особливостей, що виявляються на всіх мовних рівнях (фонетичному, лексичному, граматичному). Саме місцеві говірки часто є причиною труднощів, що виникають під час оволодіння нормами літературної мови. 
6. Проаналізувавши чинні Програми Міністерства освіти і науки України для середньої загальноосвітньої школи 1-4 класів (Програми Міністерства освіти і науки України для середньої загальноосвітньої школи $1-4$ класів (2017) та підручники з української мови, з'ясували, що жодних рекомендацій учителю мови, як працювати в умовах місцевих говірок, у них не подано, як і не натрапили ми на вправи, які були б спрямовані на вивчення літературної мови через зіставлення з діалектизмами. Однак ми не можемо не зважати на мовні реалії, на активне функціонування діалектів і на те, що вчителі, насамперед початкової школи, стикаються з питанням, за якою методикою працювати з учнями-носіями говірки, як віднайти правильний психологічний підхід до першокласника, котрому важко сприймати нові для нього літературні слова і граматичні форми, чи взагалі зважати на такий об'єктивний чинник, як говірка.

у школах Івано-Франківської, Львівської і Тернопільської областей студенти спеціальності «Початкова освіта» Прикарпатського національного університету імені Василя Стефаника під керівництвом автора статті проводили дослідження щодо формування лексичної компетенції учнів початкової школи на уроках української мови в умовах діалектного середовища. Були розроблені анкети для з'ясування ставлення вчителів до місцевої говірки, їхньої думки про вплив діалекту на результат вивчення літературної мови учнями, про використання відповідних вправ, також була розроблена і впроваджена у навчальний процес експериментальна методика 3 формування лексичної компетенції учнів-носіїв місцевого мовлення.

Результати опитування учителів засвідчили, що загалом вони не використовують спеціальних вправ, спрямованих на вивчення літературної мови крізь призму місцевої говірки, і не вважають за необхідне надавати більшої ваги діалектному мовленню, ніж зазвичай.

Результати формувального етапу експерименту, суть якого полягала у впровадженні в навчальний процес експериментального класу оригінальної системи завдань, створених для формування словника учнів в умовах діалектного середовища, засвідчили ефективність запропонованої методики. Адже проведена робота позитивно вплинула на підвищення рівня умінь і навичок учнів розрізняти подані діалектизми та літературні слова, усвідомлено обирати доречне слово, фіксувати у власному мовленні діалектизми та підміняти їх літературними відповідниками. Учні експериментальних класів в усіх дослідженнях мали кращі результати, аніж учні контрольних класів. Проаналізувавши результати виконання завдань учням експериментальних і контрольних класів до і після формувального етапу експерименту, отримали узагальнені дані (подані нижче у таблиці).

Таблиця 1

Узагальнені показники динаміки знань та умінь учнів експериментальних і контрольних груп до і після формувального експерименту

\begin{tabular}{|l|c|c|c|c|}
\hline $\begin{array}{c}\text { Рівень умінь і } \\
\text { навичок }\end{array}$ & $\begin{array}{c}\text { Експеримент. } \\
\text { група } \\
\text { до формув. } \\
\text { етапу }\end{array}$ & $\begin{array}{c}\text { Експеримент. } \\
\text { група } \\
\text { після формув. } \\
\text { етапу }\end{array}$ & $\begin{array}{c}\text { Контрольна } \\
\text { група } \\
\text { до формув. } \\
\text { етапу }\end{array}$ & $\begin{array}{c}\text { Контрольна } \\
\text { група } \\
\text { після формув. } \\
\text { етапу }\end{array}$ \\
\hline Високий & $20 \%$ & $40 \%$ & $40 \%$ & $40 \%$ \\
\hline Середній & $50 \%$ & $50 \%$ & $40 \%$ & $50 \%$ \\
\hline Низький & $30 \%$ & $10 \%$ & $20 \%$ & $10 \%$ \\
\hline
\end{tabular}

Отож, дослідження засвідчило не тільки необхідність залучення діалектного матеріалу до вивчення літературної мови у початковій школі, але й позитивний ефект від цього.

На наш погляд, формування лексичної компетенції майбутніх учителів початкових класів задля професійної діяльності в умовах діалектного середовища передбачає кілька аспектів роботи:

1) лінгводидактичний аспект:

а) з'ясування термінологічного апарату проблеми, а саме визначення суті поняття «лексична компетенція», її зв'язок і місце у системі мовно-мовленнєвих компетенцій і відносно комунікативної компетентності;

б) з'ясування змісту поняття «лексична компетенція учня початкової школи з українською мовою навчання» (у межах цієї роботи ми не розглядаємо вивчення української мови у школах з мовою національних меншин);

2) лінгвістичний аспект, що передбачає

а) удосконалення знань студентів про лексику української літературної мови, семантичні зв'язки між лексемами і вміння ці знання застосовувати на практиці;

б) розширення або формування словникового запасу діалектних лексем, що побутують на території можливого працевлаштування студентів (у нашому випадку - говірки Прикарпаття, Львівщини, Тернопільщини і Закарпаття);

в) формування позитивного ставлення студентів до діалектного мовлення і його носіїв, розуміння історичної ролі діалектів у процесі створення літературної мови і для реконструювання на сучасному етапі давньої української мови;

3) діяльнісно-практичний аспект, що передбачає використання набутих студентами знань у процесі формування їхньої готовності до педагогічної діяльності: 
а) формування умінь студентів вдало і доречно послуговуватися словниковим запасом української літературної мови і, за необхідності, українського діалектного мовлення;

б) формування умінь майбутніх учителів початкових класів організувати ефективне вивчення української літературної мови в умовах виразного діалектного середовища, не знецінюючи традиційної місцевої говірки.

Перелічені вище напрямки роботи щодо підготовки майбутніх учителів початкової школи до педагогічної діяльності в умовах діалектного середовища рекомендуємо здійснювати у процесі вивчення дисциплін мовнолітературного циклу, зокрема «Сучасна українська мова з практикумом», «Основи культури і техніки мовлення», «Методика навчання української мови», відповідні курси за вибором студентів, а також «Дитяча література», «Методика викладання дитячої літератури», адже і в художніх текстах для дітей нерідко трапляються діалектизми, які вчитель повинен уміти пояснити.

\section{ВИСНОВКИ ТА ПЕРСПЕКТИВИ ПОДАЛЬШИХ ДОСЛІДЖЕНЬ}

Отже, актуальність питання підготовки студентів спеціальності «Початкова освіта» до педагогічної діяльності в діалектному середовищі обумовлює насамперед те, що діалектне мовлення є об'єктивним і вагомим чинником формування літературного мовлення молодших школярів, а також відсутність рекомендацій для учителів початкової школи щодо вивчення мови в діалектному середовищі, за винятком незначної кількості науковометодичних розробок з цієї проблематики.

Сформованість лексичної компетенції, як і комунікативної компетентності вчителя початкової школи, є одним із ключових показників його професійної компетентності.

Перспективним напрямком подальшого опрацювання порушеної проблеми вважаємо пошук ефективних методів і прийомів, а також розробки відповідної системи роботи щодо формування готовності майбутніх учителів початкової школи до педагогічної діяльності в умовах діалектного середовища.

\section{СПИСОК ВИКОРИСТАНИХ ДЖЕРЕЛ}

Амеліна, С.М. (2014). Методика формування лексичної компетенції майбутніх філологів. Вісник Дніпропетровського університету імені Альфреда Нобеля. Серія «Педагогіка і психологія». Педагогічні науки. 2. 131-135.

Бігич, О.Б., \&Бориско Н.Ф.,\& Борецька Г.Е. (2011). Методика формування міжкультурної іншомовної комунікативної компетенції: курс лекцій: навч.-метод. посіб. За ред. С.Ю. Ніколаєвої. К.: Ленвіт.

Богуш, А.М. (1998). Змістова характеристика видів мовленнєвої компетенції дошкільників. Наука і освіта: Науково-практичний журнал Південного наукового центру АПН України. 1-2. 16 - 20.

Ватаманюк, Г. (2017). Теоретичні основи формування лексичної компетенції старших дошкільників у процесі сприйняття художніх картин. Педагогічна освіта: теорія і практика: зб. наук. праць. Кам'янець-Подільський національний університет імені Івана Огієнка, Інститут педагогіки НАПН України. Кам'янець-Подільський. Вип. 22 (1), ч. 2. $183-187$.

Вєтрова, І. (2013) Проблема формування лексичної компетенції в підготовці майбутнього вчителя іноземної мови. Обрії. 1 (36). 56-58.

Горбунова, Н. В. (2013). Лексична компетенція дітей дошкільного віку в сучасних дослідженнях. Електронний ресурс - Режим доступу: http://ps.stateuniversity.ks.ua/file/issue_59/34.pdf

Греб, М. М. (2010). Лексична і фразеологічна компетентності як провідні детермінанти лінгводидактичної підготовки вчителів початкових класів. Електронний ресурс - Режим доступу: http://ipvid.org.ua/upload/iblock/ea5/ea5f622e57941281349 4ec76a34cb784.pdf 91-101.

Державний стандарт початкової освіти (21 лютого 2018 р.) Електронний ресурс - Режим доступу https://www.kmu.gov.ua/ua/ npas/pro-zatverdzhennya-derzhavnogo-standartu-pochatkovoyi-osviti

Дудик, П.С. (2005) Стилістика української мови: навч. пос. К.: Академія.

Загальноєвропейські рекомендації з мовної освіти: вивчення, викладання, оцінювання (2003). [наук. ред. укр. вид. С.Ю.Николаєва]. К.: Ленвіт.

Климова, К.Я. (2000). Формування культури мовлення майбутніх учителів початкових класів в умовах говірок Житомирщини. Автореф. дис... канд. пед. наук: 13.00.02 Ін-т педагогіки АПН України. К. 19.

Кремень В. Г. (2005). Освіта і наука в Україні - інноваційні аспекти. Стратегія. Реалізація. Результати. К.: Грамота.

Новосьолова В. (2014). Методи, прийоми й засоби навчання в процесі формування лексичної компетентності учнів 5-7 класів. Українська мова і література в школі. 3 (113). 19-23.

Програми Міністерства освіти і науки України для середньої загальноосвітньої школи 1-4 класів (2017). Електронний ресурс - Режим доступу: https://mon.gov.ua/ua/osvita/zagalna-serednya-osvita/navchalni-programi/ navchalni-programi-dlya-pochatkovoyi-shkoli

Сіранчук, Н.М. (2018). Формування лексичної компетентності в учнів початкових класів на уроках української мови. Дисертація на здобуття наукового ступеня доктора педагогічних наук зі спеціальності 13.00 .02 «Теорія та методика навчання (українська мова)». Київський університет імені Бориса Грінченка. Київ.

Симоненкова, Л. М. (1981). Вивчення фонетики і морфології в умовах місцевих говорів. К.: Рад. школа.

Скворцова С.О. \& Вторнікова Ю.С. (2013). Професійно-комунікативна компетентність учителя початкових класів: монографія. Одеса: Абрикос Компани.

Смоліна, С.В. (2010). Методика формування іншомовної лексичної компетенції. Іноземні мови. 4. 16-23.

Стахів, М.О. (2015). Формування професійної компетентності вчителя початкових класів в умовах ступеневої вищої освіти. Молодий вчитель. Науковий журнал. 4 (19). Ч. 3. 40-43.

Федоренко, Ю. (2002). Комунікативна компетенція як найважливіший елемент успішного спілкування. Рідна школа. 1(864). 63-65.

Хом'як, І. М. (2002). Лінгво-методичні засади навчання орфографії української мови в основній школі: Автореф. дис... докт. пед. наук. Київ. 33 . 


\section{REFERENCES}

Amelina, S.M. (2014). Metodyka formuvannia leksychnoi kompetentsii maibutnikh filolohiv. Visnyk Dnipropetrovskoho universytetu imeni Alfreda Nobelia. Seriia «Pedahohika i psykholohiia». Pedahohichni nauky. 2. 131-135.

Bihych, O.B., \&Borysko N.F.,\& Boretska H.E. (2011). Metodyka formuvannia mizhkulturnoi inshomovnoi komunikatyvnoi kompetentsii: kurs lektsii: navch.-metod. posib. Za red. S.lu. Nikolaievoi. K.: Lenvit.

Bohush, A.M. (1998). Zmistova kharakterystyka vydiv movlennievoi kompetentsii doshkilnykiv. Nauka i osvita: Naukovo-praktychnyi zhurnal Pivdennoho naukovoho tsentru APN Ukrainy. 1-2. 16 - 20.

Vatamaniuk, H. (2017). Teoretychni osnovy formuvannia leksychnoi kompetentsii starshykh doshkilnykiv u protsesi spryiniattia khudozhnikh kartyn. Pedahohichna osvita: teoriia i praktyka: zb. nauk. prats. Kamianets-Podilskyi natsionalnyi universytet imeni Ivana Ohiienka, Instytut pedahohiky NAPN Ukrainy. Kamianets-Podilskyi. Vyp. 22 (1), ch. 2. 183- 187.

Vietrova, I. (2013) Problema formuvannia leksychnoi kompetentsii v pidhotovtsi maibutnoho vchytelia inozemnoi movy. Obrii. 1 (36). 56-58.

Horbunova, N. V. (2013). Leksychna kompetentsiia ditei doshkilnoho viku v suchasnykh doslidzhenniakh. Elektronnyi resurs - Rezhym dostupu: http://ps.stateuniversity.ks.ua/file/issue_59/34.pdf

Hreb, M. M. (2010). Leksychna i frazeolohichna kompetentnosti yak providni determinanty linhvodydaktychnoi pidhotovky vchyteliv pochatkovykh klasiv. Elektronnyi resurs - Rezhym dostupu: http://ipvid.org.ua/upload/iblock/ea5/ea5f622e579412813494 ec76a34cb784.pdf 91-101.

Derzhavnyi standart pochatkovoi osvity (21 liutoho 2018 r.) Elektronnyi resurs - Rezhym dostupu https://www.kmu.gov.ua/ua/npas/ pro-zatverdzhennya-derzhavnogo-standartu-pochatkovoyi-osviti

Dudyk, P.S. (2005) Stylistyka ukrainskoi movy: navch. pos. K.: Akademiia.

Zahalnoievropeiski Rekomendatsii z movnoi osvity: vyvchennia, vykladannia, otsiniuvannia (2003). [nauk. red. ukr. vyd. S.lu. Nykolaieva]. K.: Lenvit.

Klymova, K.la. (2000). Formuvannia kultury movlennia maibutnikh uchyteliv pochatkovykh klasiv v umovakh hovirok Zhytomyrshchyny. Avtoref. dys... kand. ped. nauk: 13.00.02 In-t pedahohiky APN Ukrainy. K. 19.

Kremen V. H. (2005). Osvita i nauka v Ukraini - innovatsiini aspekty. Stratehiia. Realizatsiia. Rezultaty. K.: Hramota.

Novosolova V. (2014). Metody, pryiomy y zasoby navchannia $v$ protsesi formuvannia leksychnoi kompetentnosti uchniv 5-7 klasiv. Ukrainska mova i literatura v shkoli. 3 (113). 19-23.

Prohramy Ministerstva osvity i nauky Ukrainy dlia serednoi zahalnoosvitnoi shkoly 1-4 klasiv (2017). Elektronnyi resurs - Rezhym dostupu: https://mon.gov.ua/ua/osvita/zagalna-serednya-osvita/navchalni-programi/navchalni-programi-dlya-pochatkovoyi-shkoli

Siranchuk, N.M. (2018). Formuvannia leksychnoi kompetentnosti v uchniv pochatkovykh klasiv na urokakh ukrainskoi movy. Dysertatsiia na zdobuttia naukovoho stupenia doktora pedahohichnykh nauk zi spetsialnosti 13.00 .02 «Teoriia ta metodyka navchannia (ukrainska mova)». Kyivskyi universytet imeni Borysa Hrinchenka. Kyiv.

Symonenkova, L. M. (1981). Vyvchennia fonetyky i morfolohii v umovakh mistsevykh hovoriv. K.: Rad. shkola.

Skvortsova S.O. \& Vtornikova Yu.S. (2013). Profesiino-komunikatyvna kompetentnist uchytelia pochatkovykh klasiv: monohrafiia. Odesa: Abrykos Kompany.

Smolina, S.V. (2010). Metodyka formuvannia inshomovnoi leksychnoi kompetentsii. Inozemni movy. 4. 16-23.

Stakhiv, M.O. (2015). Formuvannia profesiinoi kompetentnosti vchytelia pochatkovykh klasiv v umovakh stupenevoi vyshchoi osvity. Molodyi vchytel. Naukovyi zhurnal. 4 (19). Ch. 3. 40-43.

Fedorenko, Yu. (2002). Komunikatyvna kompetentsiia yak naivazhlyvishyi element uspishnoho spilkuvannia. Ridna shkola. 1(864). 63-65.

Khomiak, I. M. (2002). Linhvo-metodychni zasady navchannia orfohrafii ukrainskoi movy v osnovnii shkoli: Avtoref. dys... dokt. ped. nauk. Kyiv. 33 